\title{
Region-Wise Growth of Co-operatives in Karnataka: A Comparative Analysis
}

\author{
U. Yuvaraja \\ Assistant Professor, Department of PG Studies in Economics \\ Sri Dharmasthla Manjunatheshwara College (A), Ujire, Karnataka, India \\ https://orcid.org/0000-0002-4380-5269
}

Manuscript ID:

ECO-2020-08043234

Volume: 8

Issue: 4

Month: September

Year: 2020

P-ISSN: 2319-961X

E-ISSN: 2582-0192

Received: 20.06.2020

Accepted: 28.07.2020

Published: 01.09.2020

Citation:

Yuvaraja, V. "Region-Wise Growth of Co-Operatives in Karnataka: A Comparative Analysis." Shanlax International Journal of Economics, vol. 8, no. 4, 2020, pp. 29-36.

DOI:

https://doi.org/10.34293/ economics.v8i4.3234

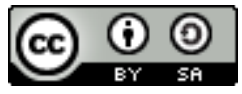

This work is licensed under a Creative Commons Attribution-ShareAlike 4.0 International License

\begin{abstract}
Today cooperatives are represented as a strong, vibrant, and viable device for achieving development goals in any country of the world. Cooperatives will meet the peoples' mutual needs. They provide exclusive tools for achieving one or more economic goals in an increasingly competitive global economy. The co-operative sector plays an imperative function in a country's socio-economic development since 1904. Karnataka has been at the forefront of co-operative endeavors and has performed well in the development of co-operatives at the national level. Cooperatives are the Self Help Organizations currently used by the government as the more effective devices for rural development. This paper is devoted to evaluating the region-wise growth of the co-operatives in Karnataka over 2010. The study is purely based on secondary data. Simple statistical tools like average, standard deviation, GCR, a percentage have been employed for the data analysis.
\end{abstract}

Keywords: Working, Co-operatives, Density, Defunct \& liquidated and Physical performance.

\section{Introduction}

The strategy of the cooperative is intended to build self-confidence and financial capabilities, especially among the rural poor. Due to the prime role of Robert Owen (1771-1858) in the cooperative movement, he was considered as the father of the cooperative movement. Countries like Britain and France (European countries) have considered the birthplaces of the co-operative movement in the 19th century. In India, the Co-operative Movement was taken birth in 1904 by the enactment of the Co-operative Societies Act 1904. Karnataka has been at the forefront of the co-operative movement and has successfully established several outstanding co-operatives. Sri Siddanagouda Sanna Ramanagouda Patil established the first Agricultural Credit Co-operative society in 1905 in the village of Kanaginal in Gadag district. Two movements viz., the independence movement, and the co-operative movement had a flowing effect on the well being of the mass in India in the last century. Independence movement was the movement of the people. And the co-operative movement has been considered the economic movement of the millions of Indian - small and marginal farmers, landless laborers, workers, members of the weaker sections of the community viz. handloom weavers, fishers, artisans, etc. Loudly say the success of the Agriculture (Green), Dairy (White), Poultry (Yellow), and Fishery (Blue) sectors is dependent on the vast cooperative network spread in the nook and corner of the country. The development of the co-operative movement in India, as well as Karnataka informal financial money lenders, crumbled under the weight of credit cooperatives and banking institutions in rural and urban conglomerations. It abated the exploitation of the situation in rural areas. The spread of the movement in the non-credit sector also followed in a big way in modern days. 


\section{Review of Literature}

Available earlier literature and documentary sources have assisted the researchers in having apparent knowledge about the research problem selected for the study. Issues relating to problems and opportunities co-operatives and rural finance have reviewed. Literature, which was conducted earlier, certainly helped the researcher to identify the research gap.

Mahendrakumar, S. and Manjuprasad (2013), in their combined research work on An Analysis of the performance of Karnataka Sate - Co-operative Housing Federation, attempted to evaluate the improvement in the Karnataka State Co-operative Housing Federation during 2002-12. The result of the study revealed that the compound growth rate of share capital is 64.9 percent, the reserve fund is 5.58 percent, borrowings are 3.58 , and another fund is 24.88 during 2002-2012. Finally, they concluded that the share capital, reserve, another fund, and borrowing loans had shown an increasing trend over the period in the state ${ }^{1}$. Raju S and Prabhu S (2014), in their research article on Performance Analysis of Employees Co-operative Societies in Thanjavur District, evaluated the financial performance of the three employee co-operative societies. The study witnessed that all the three co-operatives [(PECST),(TECSP) and ECSK)]. Added to this, the ratio of the net profit to total deposits for all the three employees' co-operatives was low. They suggested that the ECSs have to shift their dependence from thrift deposits to saving deposits with planned strategies to reduce the cost of funds and has to make an effort to attract more members for $\mathrm{ECSs}^{2}$. Indira $\mathrm{R}$, in her paper on A Study of Financial Performance of Co-operative Banks in Tumkur District, argued that even though co-operative banks catered financial the needs of poor in rural and semi-urban areas, most of these banks business volume is low because of the problem of lack of professionalism,

1. Mahendrakumar, S. and C. Manjuprasad. "An Analysis of Performance of Karnataka State Co-operative Housing Federation." International Journal of Scientific Research, vol. 2, no. 11, 2013, pp-125-127.

2. Raju, S. and S. Prabhu. "Performance Analysis of Employees Co-Operative Societies in Thanjavur District." International Journal of Informative and Futuristic Research, vol. 2, no. 2, 2014, pp. 406-411. sound management system and lack autonomy in decision making ${ }^{3}$. Mohan Kumar and V.P Mehta (2018), in their article on Performance and Prospects of Primary Agriculture Credit Societies (PACS) in Haryana During 2000-01 to 2014-15, finds out that the over the study period, the number of societies decreased at an annual compound growth rate of 11.93 percent and membership, paid-up capital share, deposits and working capital of such societies have shown increasing trend $\mathrm{d}^{4}$.

\section{Objectives of the Study}

The prime objective of the study is to analyze the current physical status of the co-operatives in Karnataka. Specific objectives set for the study are as follows.

- To analyze the growth of all types of cooperatives over 2010 in Karnataka.

- To evaluate the region-wise distribution of cooperatives in Karnataka.

- To find out district wise and region wise density of members and population per co-operative in Karnataka.

\section{Scope, Importance, and Limitations of the Study}

This study is analytical. The geographical area of the study is restricted to Karnataka State. Issues relating to the region-wise and district wise growth of co-operatives and members during the period 2010-11 to 2018-19, region-wise distribution share of co-operatives, the performance of co-operatives in Karnataka (region wise) have taken for the study. This study will not cover the performance of the individuals of co-operatives. An Analysis of the region-wise growth and distribution status of the cooperatives may be certainly showcased the definite status of co-operatives in Karnataka.

3. Indira, R. "A Study on Financial Performance of CoOperative Banks in Tumkur District." ELK Asia Pacific Journals- Special Issue..

4. Kumar, Mohit and V.P. Mehta. "Performance and Prospects of Primary Agricultural Credit Societies (PACS) in Haryana during 2000-01 to 2014-15." International Journal of Current Microbiology and Applied Sciences, vol. 7 , no. 4,2018 , pp. 20-32. 


\section{Methodology}

The present study is analytical. Geographically the present study was restricted to Karnataka state only. This study completely relied on secondary data for its analysis. The secondary has been collected from both the published and unpublished sources. Secondary Sources like books, journals, periodicals, newspapers, monographs, and like have been used for the study. The latest information regarding district and region-wise number of co-operatives has been collected through visiting http://sahakara. kar.gov.in/ (annual reports from 2010-11 to 201819), and population data for calculation of the share of the population under co-operatives have collected from the web address http://censusindia. gov.in/2011-Common/CensusData2011.html. Two thousand eleven population census data has been used for making the calculation of the Density of population per co-operative in 2017. Added to this for finding out the percentage of population covered under co-operatives used the number of members of co-operatives in 2017 and the population in 2011.

\section{Research Results, Discussion, and Interpretation}

The research results are presented, and discussion and interpretation have made contextually as follows. And the region status of co-operatives in Karnataka has discussed in several heads as follows.

\section{Year-wise Distribution of Co-operatives in Karnataka}

Data regarding the working status of cooperatives in Karnataka during the last nine years of period (from 2010-11 to 2018-19) has been provided in Table-01. During the nine years of 2010-11 to 2018-19, the working co-operatives in Karnataka increased drastically from 30963 to 38203 , which is about more that 23 percent growth in this respect. Also, it is witnessed that in all the above said periods of the total number of registered co-operatives, about 88 percent of the co-operatives belonged to working cooperatives reaming of about 12 percent of them were found registered under Defunct and liquidated co-operatives category in Karnataka. With the above, it can be argued that the internal factors like lack of communication, week entrepreneurship, week management, the regulatory framework of cooperatives, informal organization, corruption, absence of co-operatives sprit, territory, lack of human resource management and others mainly affected on the co-operative structure in Karnataka. External factors like insufficient capital, dual regulatory by RBI and societies, centralized power, lack of community support, lack of planning, week governance, and so forth have caused the failure of a huge percentage of co-operatives in Karnataka.

In table-01, column numbers 05 to 07 represented the profit and loss status of all types of co-operatives in Karnataka. Fundamentally, co-operatives were established for providing self-help and mutual help services to its members, and these are different from the other type of organization because their motive is not earning profit but to work for the development of its members. In practice, in a competitive ear, without marginal profit, it is very difficult to stay in the field for a long time. As per the 2010-11 data, about half of the co-operatives in Karnataka were not registered even marginal level of profit, and decreasing of 31.26 percent of co-operatives run with loss-making in 2018-19. Added to this, from the year 2014-15 to 2018-19, of the total, an average of about 10.15 percent of them was neither registered profit nor loss.

\section{Growth of Co-operatives in Karnataka}

Self calculated data regarding the annual growth rate of the total, working, and defunct cooperatives in Karnataka, during 2010-11 and 201819, has been provided in Table-02. During the nine years from 2010-11 to 2018-19, the total number of co-operatives and Working co-operatives have registered an annual average of about 2.61 and 2..32 percent of the growth in Karnataka in that order. Supporting the former, both the above said types of cooperatives had registered about 23 to 24 percent growth over the year 2010-11 in Karnataka. It is worth noting that the growth rate of the defunct and liquidated co-operatives was about 20.48 percent over 2010-11 and registered high of 10.38 and 8.79 percent in 2013-14 and 2018-19.

\section{Region-wise Distribution of Co-operatives in Karnataka}

Data connecting to the region-wise distribution of co-operatives as of 2017 in Karnataka has presented 
in Table-03. Of the total working co-operatives, the highest of 32.37 percent of them found registered in Bangalore division, followed by 29.52 and 24.61 percent in Belgaum and Mysore divisions, respectively. Gulbarga division is logged behind in all-round development; once again, it has proved from the data that of the total number of working co-operatives, very less of 13.50 percent of them activated in Gulbarga division. Added to this, about 5183 out of total co-operatives have found registered as defunct and liquidated types, which were nearly 12.46 percent share in this respect. The region-wise highest percentage of defunct and liquidated cooperatives has recorded in the regions of Gulbarga (24.48), followed by 12.74 and 11.95 pe cent in Belgaum and Bangalore divisions in that order.

\section{Region-Wise Membership and Population density Per Co-operative}

Self calculated data in association with the regionwise share of the co-operatives member in total population and density in working co-operatives has been provided in Table-04. It is astonishing that in the Belgaum division of the total population highest of about 51.87 percent of the population has registered their name one or other types of co-operatives, followed by 39.90 and 34.58 percent in Mysore and Gulbarga Divisions respectively. Added to this, the total population (2011 census) of Bangalore division low of about 26.77 has come under the co-operative regime in 2017. Over all, (as per the 2011 population census data) of the total population in Karnataka, about 36.98 percent of them registered their name under the co-operatives regime in 2017.

Data relating to the category wise share of cooperative members in the respective population has been provided in column 03 and 04 of Table- 04 . As per the calculation of the total SCs and ST population, about 27.83 and 31 percent of them have taken the co-operative society membership in Karnataka as of 2017 in that order. A high percentage of SCs and ST members were found registered in the regions of Bangalore (31.45) and Belgaum (37.70), respectively. The contrary, a low percentage of SCs and ST populations were covered under the cooperative regime in Mysore-Gulbarga and Gulbarga division in that order.
Self calculated data in column 05 and 06 of Table-04 provided the information regarding the region-wise population and members' density per working co-operatives in Karnataka. The researcher has used data regarding co-operatives and their member status as of 2017 and Population as of the 2011 census for calculating the density of the population per working co-operatively. As per the calculation density of the members per working cooperative and population per working co-operatively in the state was 620.70 and 1678.25 , respectively. Region-wise data revealed that the density of the members per working co-operatives is low in Bangalore and Mysore Division and high in Belgaum and Gulbarga Division. Added to this, the Gulbarga division has registered the highest of 2282.76 persons per co-operative, followed by the secondhighest of 1911.34 per person per co-operative in Bangalore division. Population density per working co-operative is low in the regions of Belgaum and Mysore divisions.

\section{District wise Membership and Population density per Co-operatives}

District wise self calculated statistical data regarding membership and density status of the co-operatives had been presented in Table-05. As per the data, of the total population of the districts like Yadgir, Karwar, Belgaum and Bagalkot high of about 79.30, 70.07, 65.13 and 62.56 percent registered under the co-operative regime. Added to this, the total population of Shimoga, Mangalore, Mandya, Chitradurga, Hassan, Udupi, Haveri Vijayapura, Madikeri, Tumkur districts about an average 45 percent has taken the membership under different types of co-operatives. Less percentage of population registered under the co-operative regime in the districts of Bangalore Urban (19.56), Raichur (19.80), Dharwad (22.34), and Koppal (24.60). It can also be seen from the data that of the total SC population of the districts, huge of about 43.49, 42.48 , and 40.14 percent they have registered their name under co-operative societies in the districts of Bangalore Rural, Baglkote, and Tumkur. As against districts like Bangalore Urban (11.10), Kolar (9.18), Chamarajnagar (14.81), Chikkaballapur (15.10) Koppal (13.61) have registered low population 
cover under a co-operative system in the state. Members' density per working co-operatives has been high in the districts of Yadgir (1737), Karwar (1278), Mangalore (1180), Chitradurga (933) and Madikeri (925). Contrary, Districts like Kolar (338), Chikballapur (374), Mysore (394), Bangalore Rural (394), and Davanager (407) have registered low members density per working co-operatively in the state (2017).

\section{Findings of the Study}

Based on the earlier interpretation, findings of the present micro-level study are listed as follows.

- Of the total registered co-operatives, an average of about 88 percent of the co-operatives was providing co-operative services remaining 12 percent was in Defunct \& liquidated form Cooperatives.

- The total number of co-operatives in Karnataka have registered 23.01 percent growth during the period between 2010-11and 2018-19, which was an average of 2.61 percent of annual growth.

- Defunct \& liquidated Co-operatives in Karnataka have registered about 20 percent growth from the last nine years period from 2010-11 to 2018-19.

- Highest and Lowest Defunct \& liquidated Cooperatives have been located in the regions of Gulbarga (24.48\%) and Mysore (4.50\%), respectively.

- As of 2017, of the total number of co-operatives highest of 32.37 percent and lowest of 13.38 percent of co-operatives found registered in Bangalore and Gulbarga divisions respectively

- As on the 2011 census, of the total population of the Belgaum division, the highest of about 51.87 percent of them came under the co-operative regime, which was very low in Bangalore Division, where only 26.77 percent was covered.

- of the total population of the districts like Yadgir, Karwar, Belgaum and Bagalkot high of about $79.30,70.07,65.13$ and 62.56 percent registered under the co-operative regime

- of the total SC population of the districts, huge of about $43.49,42.48$, and 40.14 percent they have registered their name under co-operative societies in the districts of Bangalore Rural, Baglkote, and Tumkur

\section{Conclusion}

Cooperatives and mutual societies are important players in the social economy and rural development. On several occasions, our governments, and policy makers have underlined their increasing importance for the all-round development of local communities, and social inclusion. Cooperatives seek wider recognition and better integration of their business model. However, difference in the region-wise development of co-operatives has contributed for the underdevelopment of the areas. Cooperatives must play the role of a Third Force, an alternative and countervailing power to abate regional disparities. The distinctive aspect of the cooperative business is its dual character as a social organization and economic enterprise. One form, an economy based, the business association is neither desirable nor possible alone in modern times. The most excellent economic order is confirmed through a mixed economy. In this regard, development cooperatives must be considered a unique tool for solving some of the massive problems of the country as a whole and rural region particular.

Table 1: Year Wise Status of Co-operatives in Karnataka-2010-11 to 2018-19

\begin{tabular}{|c|c|c|c|c|c|c|}
\hline Year & $\begin{array}{c}\text { Total No. of } \\
\text { Co-operatives }\end{array}$ & $\begin{array}{c}\text { Working } \\
\text { Co-operatives }\end{array}$ & $\begin{array}{c}\text { Defunct \& } \\
\text { liquidated Co- } \\
\text { operatives }\end{array}$ & $\begin{array}{c}\text { No. of } \\
\text { Co-operatives } \\
\text { under profit }\end{array}$ & $\begin{array}{c}\text { No. of } \\
\text { co-operative } \\
\text { under loss }\end{array}$ & $\begin{array}{c}\text { No. of co- } \\
\text { operative } \\
\text { societies with no } \\
\text { profit/ no loss }\end{array}$ \\
\hline$(01)$ & $(02)$ & $(03)$ & $(04)$ & $(05)$ & $(06)$ & $(07)$ \\
\hline $2010-11$ & 35502 & $30963(87.21)$ & $4539(12.79)$ & $17732(49.94)$ & $17,770(50.06)$ & -- \\
\hline $2011-12$ & 36481 & $32029(87.80)$ & $4452(12.20)$ & $19963(54.72)$ & $16,518(45.28)$ & -- \\
\hline $2012-13$ & 37468 & $33172(88.53)$ & $4296(11.47)$ & $21017(56.10)$ & $16,451(43.90)$ & -- \\
\hline $2013-14$ & 38,430 & $33,717(87.73)$ & $4742(12.27)$ & $22,209(57.80)$ & $16,221(42.20)$ & -- \\
\hline
\end{tabular}


International Journal of Economics

\begin{tabular}{|c|c|c|c|c|c|c|}
\hline $2014-15$ & 39,627 & $34,664(87.47)$ & $4963(12.53)$ & $21,631(54.58)$ & $13,624(34.38)$ & $4,372(11.04)$ \\
\hline $2015-16$ & 40,643 & $35,589(87.56)$ & $5054(12.46)$ & $23,307(57.34)$ & $13,514(33.25)$ & $3,822(9.41)$ \\
\hline $2016-17$ & 41,402 & $36,345(87.78)$ & $5057(12.22)$ & $24,619(59.46)$ & $12,399(29.94)$ & $4,384(10.60)$ \\
\hline $2017-18$ & 42543 & $37,516(88.18)$ & $5027(11.82)$ & $24,888(58.50)$ & $13,901(32.67)$ & $3,754(8.83)$ \\
\hline $2018-19$ & 43,672 & $38,203(87.47)$ & $5469(12.53)$ & $25,271(57.86)$ & $13,652(31.26)$ & $4,749(10.88)$ \\
\hline
\end{tabular}

Source: Self Calculated Data, Annual Reports of Sahakara Sindhu from 2010-11 to 2018-19 (http://sahakara.kar.gov.in/)

Table 2: Growth of Co-operatives over the years in Karnataka

\begin{tabular}{|c|c|c|c|}
\hline Year & $\begin{array}{c}\text { Total No. of Co-operatives } \\
\text { (growth over the year in \%) }\end{array}$ & $\begin{array}{c}\text { Working Co-operatives } \\
\text { (Growth over the year in \%) }\end{array}$ & $\begin{array}{c}\text { Defunct \& liquidated Co- } \\
\text { operatives } \\
\text { (Growth over the year in \%) }\end{array}$ \\
\hline$(01)$ & $(02)$ & $(03)$ & $(04)$ \\
\hline $2010-11$ & -- & -- & -- \\
\hline $2011-12$ & 2.75 & 3.44 & -1.91 \\
\hline $2012-13$ & 2.70 & 3.56 & -3.50 \\
\hline $2013-14$ & 2.56 & 1.64 & 10.38 \\
\hline $2014-15$ & 3.11 & 2.80 & 4.66 \\
\hline $2015-16$ & 2.56 & 2.66 & 1.83 \\
\hline $2016-17$ & 1.86 & 2.08 & 0.05 \\
\hline $2017-18$ & 2.75 & 3.22 & -0.59 \\
\hline $2018-19$ & 2.65 & 1.83 & 8.79 \\
\hline $\begin{array}{c}\text { \% growth } \\
\text { over 2010-11 }\end{array}$ & \begin{tabular}{c}
2.61 Annual average) \\
\hline
\end{tabular} & $(2.32$ Annual average) & 20.48 \\
\hline
\end{tabular}

Table 3: Region-wise Distribution of Co-operatives in Karnataka (2017)

\begin{tabular}{|l|c|c|c|c|}
\hline Name of the Division & Working Co-operative & Defunct & Total No. of co-operatives & $\mathbf{3 6 4 0 4 / ( 0 2 )}$ \\
\hline \multicolumn{1}{|c|}{$(01)$} & $(02)$ & $(03)$ & $(05)$ & \\
\hline Belgaum Division & $10747(87.26)$ & $1568(12.74)$ & $12315(100)$ & 29.52 \\
\hline Gulbarga Division & $4913(75.51)$ & $1593(24.48)$ & $6506(100)$ & 13.50 \\
\hline Bangalore Division & $11784(88.05)$ & $1599(11.95)$ & $13383(100)$ & 32.37 \\
\hline Mysore Division & $8960(95.50)$ & $423(4.50)$ & $9385(100)$ & 24.61 \\
\hline Karnataka & $36404(87.55)$ & $5183(12.46)$ & $41589(100)$ & 100 \\
\hline
\end{tabular}

Source: Self Calculated Data, Annual Reports of Sahakara Sindhu from 2010-11 to 2018-19 (http://sahakara.kar.gov.in/)

Table 4: Region Wise Membership and Population density Per Co-operative

\begin{tabular}{|l|c|c|c|c|c|}
\hline \multirow{2}{*}{$\begin{array}{c}\text { Name of the } \\
\text { Division }\end{array}$} & \multicolumn{3}{|c|}{ Membership Details } & \multicolumn{2}{c|}{ Population per co-operatives } \\
\cline { 2 - 6 } & $\begin{array}{c}\text { Membership } \\
\text { (Actual)\% }\end{array}$ & SC\% & ST\% & $\begin{array}{c}\text { Members Density per } \\
\text { working co-operative }\end{array}$ & $\begin{array}{c}\text { Population per } \\
\text { working co-operative }\end{array}$ \\
\hline \multicolumn{1}{|c|}{$(01)$} & $(02)$ & $(03)$ & $(04)$ & $(05)$ & $(06)$ \\
\hline Belgaum Division & 51.87 & 27.46 & 37.70 & 713.10 & 1376.49 \\
\hline Gulbarga Division & 34.58 & 24.93 & 21.42 & 789.53 & 2282.76 \\
\hline Bangalore Division & 26.77 & 31.45 & 34.95 & 511.67 & 1911.34 \\
\hline Mysore Division & 39.90 & 24.52 & 35.64 & 559.60 & 1402.18 \\
\hline Karnataka & 36.98 & 27.83 & 31.00 & 620.70 & 1678.25 \\
\hline
\end{tabular}

Source: Self Calculated Data, Annual Reports of Sahakara Sindhu from 2010-11 to 2018-19 (http://sahakara.kar.gov.in/) and 2011 Population census data (http://censusindia.gov.in/2011-Common/CensusData2011) 
Table 5: District wise Membership and Population density per Co-operatives (2017)

\begin{tabular}{|c|c|c|c|c|c|c|c|c|c|c|c|}
\hline 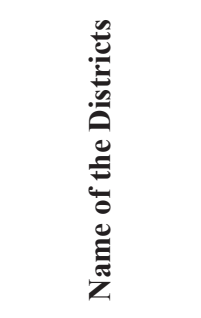 & 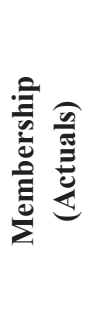 & 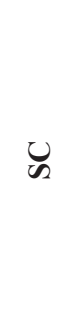 & 证 & 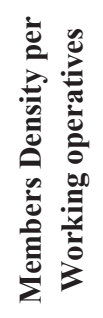 & 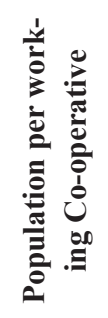 & 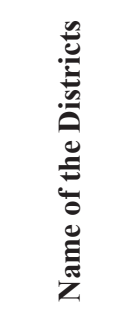 & 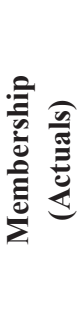 & U & $\sqrt[H]{ }$ & 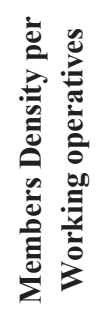 & 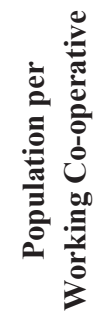 \\
\hline (01) & $(02)$ & (03) & (04) & $(05)$ & (06) & $(07)$ & (08) & (09) & (10) & (11) & (12) \\
\hline $\begin{array}{l}\text { Bangalore } \\
\text { Urban }\end{array}$ & 19.56 & 11.10 & 18.14 & 835.20 & 4268.65 & Hassan & 42.30 & 23.15 & 72.90 & 440.13 & 1040.05 \\
\hline Bangalore Rural & 38.87 & 43.49 & 40.92 & 394.25 & 1014.25 & Udupi & 48.90 & 26.46 & 55.22 & 909.56 & 1859.96 \\
\hline Chikkaballapur & 36.26 & 15.10 & 18.71 & 374.05 & 1031.30 & Bellary & 33.75 & 29.22 & 25.82 & 837.93 & 2457.51 \\
\hline Chitradurga & 41.03 & 25.72 & 31.13 & 933.98 & 2276.34 & Bidar & 27.86 & 19.78 & 8.71 & 563.07 & 2020.52 \\
\hline Davanagere & 26.69 & 16.65 & 28.04 & 407.07 & 1531.88 & Koppal & 24.60 & 13.61 & 11.02 & 594.63 & 2417.25 \\
\hline Kolar & 27.10 & 9.18 & 23.02 & 338.14 & 1248.09 & Kalburgi & 35.90 & 27.43 & 35.70 & 844.48 & 2352.26 \\
\hline Ramnagara & 38.76 & 26.10 & 78.32 & 378.79 & 977.10 & Raichur & 19.80 & 28.93 & 22.15 & 438.98 & 2217.02 \\
\hline Shimoga & 40.82 & 21.28 & 45.06 & 651.16 & 1594.86 & Yadgir & 79.30 & 23.30 & 31.96 & 1737.40 & 2190.80 \\
\hline Tumkur & 44.84 & 40.14 & 70.29 & 632.58 & 1410.73 & Belgaum & 65.13 & 23.05 & 44.78 & 652.89 & 1002.44 \\
\hline Mysore & 29.28 & 25.30 & 26.17 & 394.02 & 1320.91 & Bagalkote & 62.56 & 42.50 & 64.07 & 839.66 & 1342.15 \\
\hline Mangalore & 45.53 & 26.15 & 43.50 & 1180.62 & 2592.61 & Dharwad & 22.34 & 21.48 & 18.48 & 520.39 & 2329.15 \\
\hline Madkeri & 50.55 & 30.36 & 40.61 & 925.29 & 1830.09 & Gadag & 35.80 & 19.00 & 20.48 & 474.70 & 1325.74 \\
\hline Mandya & 48.07 & 34.89 & 75.81 & 437.80 & 910.62 & Haveri & 42.48 & 18.60 & 19.88 & 699.79 & 1647.08 \\
\hline Chikmagalur & 33.65 & 20.57 & 65.32 & 728.15 & 2163.42 & Karwar & 70.07 & 37.50 & 41.20 & 1278.10 & 1823.80 \\
\hline Chamarajanagar & 30.19 & 14.81 & 17.00 & 422.82 & 1400.26 & Vijayapura & 41.25 & 29.85 & 49.58 & 738.00 & 1789.10 \\
\hline
\end{tabular}

Source: Self Calculated Data, Annual Reports of Sahakara Sindhu from 2010-11 to 2018-19 (http://sahakara.kar.gov.in/) and 2011 Population census data (http://censusindia.gov.in/2011-Common/CensusData2011)

\section{References}

2011 Census Data, Ministry of Home Affairs, Government of India, https://censusindia.gov. in/2011-common/censusdata2011.html.

Amin, Md. Ruhul, and Mohammed Mahin Uddin. "Socio-Economic Impacts of Co-operative Societies: An Empirical Study." Socrates, vol. 2, no. 2, 2014, pp. 179-193.

Annual Reports from 2010-11 to 2018-19, Sahakara Sindhu, Department of Cooperation, Government of Karnataka, http://sahakara. kar.gov.in/report.html.

Basu, Pratyusha. Villages, Women and the Success of Dairy Co-operatives in India: Making Place for Rural Development, Cambria Press, 2009. Bhuimali, Anil. Rural Co-operative and Economic Development, Sarup and Sons, 2003.
Bhulal, Vipan Kumar and Sonika Dhanna. "A Study on Cooperative Banks with Special Reference to Himachal Pradesh Co-operative Bank." IOSR Journal of Humanities and Social Science, vol. 22, no. 12. 2017, pp. 67-73.

Gupta, Jyoti and Suman Jain. "A Study on Cooperative Banks in India with Special Reference to Lending Practices." International Journal of Scientific and Research Publications, vol. 2, no. 10, 2012, pp. 1-6.

Kerswell, Timothy and Surendra Pratap. Worker Cooperatives in India, Palgrave Macmillan, 2018.

Khandare, B.D. Growth of Sugar Cooperatives and Economic Development, Serials Publications, 2007.

Khumalo, Prudence. "Improving the Contribution of Cooperatives as Vehicles for Local Economic 
Development in South Africa." African Studies Quarterly, vol. 14, no. 4, 2014, pp. 61-78.

Madan, G.R. Co-Operative Movement in India: A Critical Appraisal, Mittal Publications, 2007.

Mahendrakumar, S., and C. Manjuprasad. "An Analysis of Performance of Karnataka State Co-operative Housing Federation." International Journal of Scientific Research, vol. 2, no. 11, 2013, pp. 125-127.

Mahesh Kumar, M. "Cooperative Movements in Karnataka: Society Structure and Growth." International Journal of Trend in Scientific Research and Development, vol. 3, no. 4. 2019, pp. 854-861.

Manjuprasad, C., and S. Mahendrakumar. "Performance of Primary Agricultural Credit Co-operatives in Karnataka." Global Journal for Research Analysis, vol. 8. no. 11, 2019, pp-11-13.

Merrett, Christopher D., and Norman Walzer. $A$ Cooperative Approach to Local Economic Development, Quorum Books, 2001.
Okem, Andrew. Theoretical and Empirical Studies on Co-operatives: Lessons for Cooperatives in South Africa, Springer International Publishing, 2016.

Rameshkumar, S., and T. Priyanga. "Co-Operative Movement in India and Abroad - Challenges and Opportunities." International Journal of Management and Social Sciences, vol. 8, no. 2.2, 2014, pp. 27-31.

Ravichandran, K., and V. Alagu Pandian. "An Economic Analysis of Visvesvarya Urban Cooperative Bank." International Journal of Management and Social Sciences Research, vol. 2. no. 1, 2013, pp. 62-69.

Smith, Stephen C., and Jonathan Rothbaum. Cooperatives in a Global Economy: Key Economic Issues, Recent Trends, and Potential for Development, IZA Policy Paper No. 68, 2013.

Tesfamariam, Kifle. "Cooperative Movement in Ethiopia: Development, Challenges and Proposed Intervention." Journal of Economics and Sustainable Development, vol. 6. no. 5, 2015, pp. 38-45.

\section{Author Details}

Dr. U. Yuvaraja, Assistant Professor, Department of PG Studies in Economics, Sri Dharmasthla Manjunatheshwara College (A), Ujire, Karnataka, India, Email ID: yuvarajget@gmail.com 